\title{
Booming: A life-changing philosophy for ageing well
}

M. Riley. Ventura Press, Sydney, NSW, 2018. ISBN 978-1-925384-45-1, ISBN ePUB: 978-1-925384-46-8,

\section{A \$32.99 (paperback) ebook $A \$ 9.99$}

Marcus Riley has had a long career in ageing. He is currently chairman of the Global Ageing Network and a member of the governing committee of the Global Alliance for the Rights of Older Persons. Marcus has an extended association with a charitable aged care services organisation based in Queensland, where he is now the chief executive officer.

The author brings his extensive experience of the aged care sector and his background to give a very Australian perspective on growing older in this country. The book is aimed at older Australians. Its goal is to help them to consider optimising how they live their remaining years. Chapter by chapter, the book promotes positive thinking, engagement, planning, having a sense of purpose, adapting to one's circumstances and overcoming ageism. The book draws upon the evidence base, but is not referenced. It is targeted directly at the lay reader: as such, it is easy to read. The text is peppered with 'case studies' of older Aussies who have 'boomed' that older readers will certainly relate to.

Personally I found the content rather 'Polyanna-esque'. But I recognise that the book's goal is to encourage personal development and so I guess an emphasis on positive thinking is relevant.

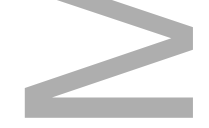

Jane Sims

Deputy Editor in Chief, Australasian Journal on Ageing

Department of General Practice, School of Primary and Allied Health Care, Monash University,

General Practice, Melbourne Medical School, University of Melbourne.

Email: jane.sims@monash.edu

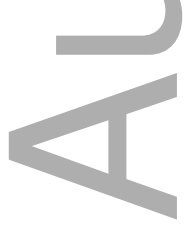

This is the author manuscript accepted for publication and has undergone full peer review but has not been through the copyediting, typesetting, pagination and proofreading process, which may lead to differences between this version and the Version of Record. Please cite this article as doi: $\underline{10.1111 / A J A G .12766}$

This article is protected by copyright. All rights reserved 


\section{University Library}

\section{- M M N E R VA A gateway to Melbourne's research publications}

Minerva Access is the Institutional Repository of The University of Melbourne

Author/s:

Sims, J

Title:

Booming: A life-changing philosophy for ageing well

Date:

2020-03-01

Citation:

Sims, J. (2020). Booming: A life-changing philosophy for ageing well. AUSTRALASIAN JOURNAL ON AGEING, 39 (1), pp.81-81. https://doi.org/10.1111/ajag.12766.

Persistent Link:

http://hdl.handle.net/11343/275495 